\title{
Cytosine 5-hydroxymethylation regulates VHL gene expression in renal clear cell carcinoma
}

\author{
En-Guang $\mathrm{Ma}^{1,2,}{ }^{*}$, Yu-Feng $\mathrm{Bai}^{1, *}$, Wei $\mathrm{Cao}^{3}$, Yan $\mathrm{CaO}^{4}$, Yong-Gang Huang ${ }^{2}$, Huan- \\ Chen Cheng ${ }^{5}$ and Rui-Hua An $^{1}$ \\ ${ }^{1}$ The Department of Urology, The First Affiliated Hospital of Harbin Medical University, Harbin, China \\ ${ }^{2}$ The Department of Urology Surgery, The First Hospital of Harbin, Harbin, China \\ ${ }^{3}$ The Department of Urinary Surgery, The Second Affiliated Hospital of Harbin Medical University, Harbin, China \\ ${ }^{4}$ The Department of Urology, Harbin Medical University Cancer Hospital, Harbin, China \\ ${ }^{5}$ Institute of Harbin Hematology \& Oncology, The First Hospital of Harbin, Harbin, China \\ "These authors have contributed equally to this work \\ Correspondence to: Rui-Hua An, email: anruihua1234@163.com \\ Keywords: DNA methylation, hydroxymethylation, VHL, renal clear cell carcinoma \\ Received: February 13, $2017 \quad$ Accepted: May 23, $2017 \quad$ Published: July 07, 2017 \\ Copyright: Ma et al. This is an open-access article distributed under the terms of the Creative Commons Attribution License 3.0 \\ (CC BY 3.0), which permits unrestricted use, distribution, and reproduction in any medium, provided the original author and source \\ are credited.
}

\section{ABSTRACT}

Cytosine5-hyxymethylation ( $5 \mathrm{hmC}$ )which is a new epigenetic modification form plays important roles in the development and progression of tumors. In the present study, we observed that levels of $5 \mathrm{hmC}$ in the promoter region of Von Hippel-Lindau (VHL) were lower in 97 samples of renal clear cell carcinoma tissue than in matched adjacent benign tissues. Moreover, when the cancer tissue samples were divided based on pathological staging, VHL expression and the level of $5 \mathrm{hmC}$ in the VHL promoter were both lower in pathological grade III tumors than in grades I or II. Correspondingly, expression of TET1, which catalyzes the formation of $5 \mathrm{hmC}$, was also lower in grade III renal clear cell carcinomas than in grade I or II disease. These findings suggest the $5 \mathrm{hmC}$ level on VHL is a key determinant of the gene's expression and may participate in the occurrence and development of renal clear cell carcinoma. Thus the $5 \mathrm{hmC}$ level may be a useful indicator for early diagnosis and appropriate treatment of renal clear cell carcinoma.

\section{INTRODUCTION}

Renal clear-cell carcinoma (RCC) is a renal cortical tumor characterized by malignant cells with clear cytoplasm. RCCs account for $75 \%$ of kidney cancers [1], and the incidence of RCC has been increasing in recent years. Treatment for RCC is dominated by surgery. The curative effects of radiotherapy and chemotherapy, and thus the long-term prognosis after treatment, are poor [2]. Both surgical treatment and chemotherapy were closely related to disease grade. Consequently, early diagnosis, staging and treatment of RCC are crucial.

Methylation of cytosine to 5-methycytosine $(5 \mathrm{mC})$ is a well-studied epigenetic mechanism of gene regulation [3]. Changes in $5 \mathrm{mC}$ can be detected early during tumor- igenesis, and $5 \mathrm{mC}$ is involved in both the development and progression of tumors [4]. The ten-eleven-translocation (TET) family of enzymes are able to convert $5 \mathrm{mC}$ to 5 -hydroxymethylcytosine $(5 \mathrm{hmC})$, which facilitates gene expression [5]. This newly identified epigenetic modification is mainly distributed at gene transcription enhancer and insulator binding sites [6]. Kraus et al [7] reported that $5 \mathrm{hmC}$ levels were significantly lower in brain tumor tissues than normal brain tissues. Orr et al [8] showed that reductions in $5 \mathrm{hmC}$ levels are related to the degree of tumor malignancy in nerve glioma. In addition, Thomson et al [9] showed that changes in $5 \mathrm{hmC}$ levels occur earlier than changes in $5 \mathrm{mC}$, and that the changes are very stable. This suggests the $5 \mathrm{hmC}$ level is a potential marker for early tumor diagnosis and may be predictive 
of prognosis. But although there have been a number of studies comparing $5 \mathrm{hmC}$ levels between tumors and control tissues, only Wielscherc et al has demonstrated changes $5 \mathrm{hmC}$ on a single gene (LZTS1) in cancer (breast cancer) [10].

Von Hippel-Lindau (VHL) is a tumor suppressor gene involved in oxygen and energy-dependent promotion of protein ubiquitination and proteosomal degradation [11]. In humans, VHL gene is located on chromosome $3 q 25.26$ and includes two isoforms: pVHL19 and pVHL30. The tumor suppressor effect of VHL protein disappeared when the two alleles of VHL gene were mutated or inactivated, leading to the occurrence of RCC [12]. VHL gene, whose product inhibits induction of tumor cell proliferation by Jade-1 or HIF-1, is the most studied gene in RCC [13]. Lutz et al [14] reported that inactivation of VHL expression influenced the polarization of tubular epithelial cells and the formation of primary cilia, which led to the occurrence of RCC. In that context, and taking into consideration that $5 \mathrm{hmC}$ and $5 \mathrm{mC}$ levels within the genome are usually maintained in relative balance [15], we investigated $5 \mathrm{mC}$ and $5 \mathrm{hmC}$ levels on VHL gene as a potential marker for diagnosis, staging and treatment of RCC.

\section{RESULTS}

\section{Analysis of VHL expression and $5 \mathrm{mC}$ in $\mathrm{RCC}$ and adjacent benign tissues}

Real-time PCR results showed that levels of VHL mRNA were significantly lower in RCC tissue than in matched adjacent benign tissue (Figure 1A). Correspondingly, Western blot results showed that levels of VHL protein were also significantly lower in RCC than adjacent benign tissues (Figure 1D). When the RCC tissues were divided into different pathological grades, no difference in the levels of VHL mRNA or protein were detected between grades I and II. By contrast, but levels of both VHL mRNA and protein were significantly reduced in grade III (Figure 1B and 1E)

We chose four MspI sites (S1, S2, S3 and S4) in the promoter and 5' untranslated regions of VHL to analyze $5 \mathrm{mC}$ and $5 \mathrm{hmC}$ levels. Figure 2 presents a structure diagram of the VHL promoter region. The fragment used for PCR product sequencing includes $27 \mathrm{CG}$ dinucleotides that cover three $M s p I$ sites (S1, S2 and S3). The levels of $5 \mathrm{mC}$ at the $27 \mathrm{CG}$ dinucleotides did not significantly differ between the RCC and matched adjacent benign tissues (Figure 3C). However, the real-time PCR results showed that $5 \mathrm{mC}$ at $\mathrm{S} 1$ was significantly higher in RCC tissues than adjacent benign tissues, but the difference was not significant at S2-S4. When we measured the $5 \mathrm{mC}$ levels at $\mathrm{S} 1$ in RCC tissues at different pathological grades, we detected no difference among the three pathological grades (Figure $3 \mathrm{~A}$ and $3 \mathrm{~B}$ ).

\section{VHL $5 \mathrm{hmC}$ is significantly decreased in patients with grade III RCC}

Although VHL expression was significantly lower pathological grade III RCC tissue than in grades I and II, the difference in $5 \mathrm{mC}$ levels did not significantly differ among the three grades. This suggests $5 \mathrm{mC}$ in our detected regions does not influence VHL expression. For that reason, we next examined levels of VHL $5 \mathrm{hmC}$ in RCC and adjacent benign tissues. Real-time PCR results indicated that $5 \mathrm{hmC}$ levels at $\mathrm{S} 3$ were significantly lower in RCC tissues than adjacent benign tissues (Figure 4A). Moreover, $5 \mathrm{hmC}$ at $\mathrm{S} 3$ was significantly lower in grade III RCC tissue than in grades I and II tissues (Figure 4B).

\section{TET1 could regulate VHL $5 \mathrm{hmC}$}

Ten-eleven translocation methylcytosine dioxygenase 1 (TET1) and TET2 are $5 \mathrm{mC}$ hydroxylases, which catalyze the conversion of $5 \mathrm{mC}$ into $5 \mathrm{hmC}$. We therefore assessed expression of TET1 and TET2 to further study the mechanism of the $5 \mathrm{hmC}$ reduction $\mathrm{RCC}$ tissue. Real-time quantitative PCR results showed that TET1 mRNA levels were significantly lower in RCC than matched adjacent benign tissues, while TET2 expression did not differ between the two tissue types (Figure 1A). Moreover, as with VHL, TET1 transcription was significantly lower in pathological grade III RCC tissue than grades I and II (Figure 1C). Using western blotting, we detected corresponding differences in the levels of TET1 protein (Figure 1D and 1E).

\section{DISCUSSION}

$\mathrm{RCC}$ originates from the renal parenchyma is one of the most common malignant tumors of the urinary system. Although there has been substantial progress in the diagnosis and treatment of RCC, the prognosis of RCC with distant metastasis remains poor [16]. It is therefore necessary to identify new molecular markers enabling the early diagnosis and treatment of RCC. Although $5 \mathrm{hmC}$ is reportedly important for regulating gene expression [17], there are no reports on RCC-related changes in $5 \mathrm{hmC}$ levels on single genes. In the present study, we found that expression levels of the tumor suppressor VHL are much lower in RCC tissues than adjacent benign tissues, and the expression is significantly lower in pathological grade III disease than in grades I and II. VHL may thus play a key role in the occurrence and development of RCC.

It is now well established that DNA methylation at the $\mathrm{C} 5$ position of the cytosine bases $(5 \mathrm{mC})$ is an epigenetic modification of the mammalian genome that is important in transcriptional regulation [3]. Hypermethylation of $\mathrm{CpG}$ islands within the promoter and 5' regions of genes is an important epigenetic mechanism for suppressing gene expression [4]. In our 
study, no difference in $5 \mathrm{mC}$ levels was detected between RCC tissues and matched adjacent benign tissues. Although the $5 \mathrm{mC}$ level at S1 was significantly increased in RCC tissues, there was no obvious difference at the S2-S4 sites between RCC tissues and adjacent benign tissues. Moreover, the level of $5 \mathrm{mC}$ at $\mathrm{S} 1 \mathrm{did}$
A

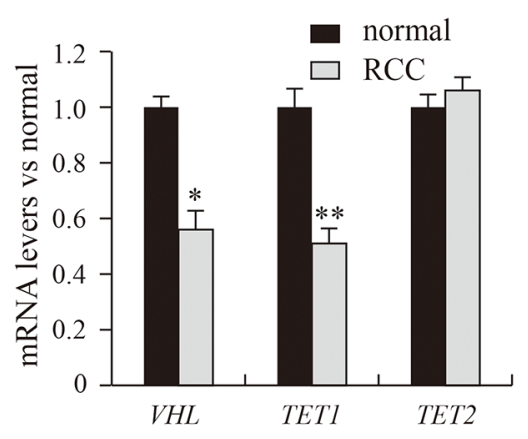

$\mathrm{D}$
B

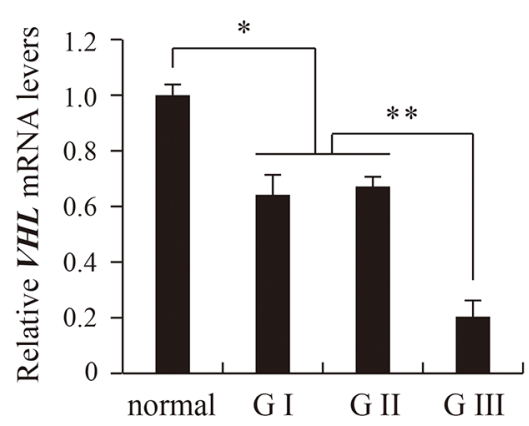

C

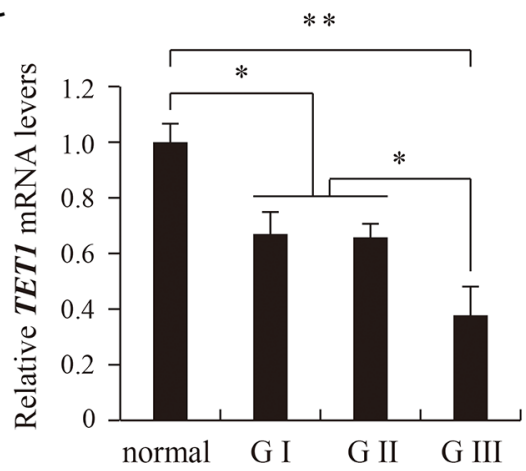

E

normal RCC
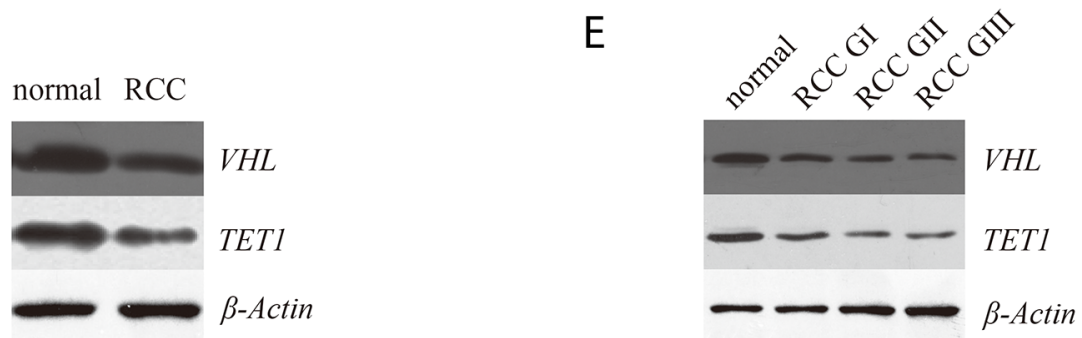

Figure 1: Analysis of VHL, TET1 and TET2 expression using real time PCR (A, B, C) and western blotting (D, E). RCC and normal indicate renal clear cell carcinoma and matched adjacent benign tissues. $\mathrm{G}$ indicates the pathological grade of RCC. ${ }^{*} P<0.05$, ** $P<0.01$ vs. normal. There were corresponding differences in expression of VHL and TET1 mRNA and protein between normal and RCC tissue (D) and between the different pathological grades of RCC (E).

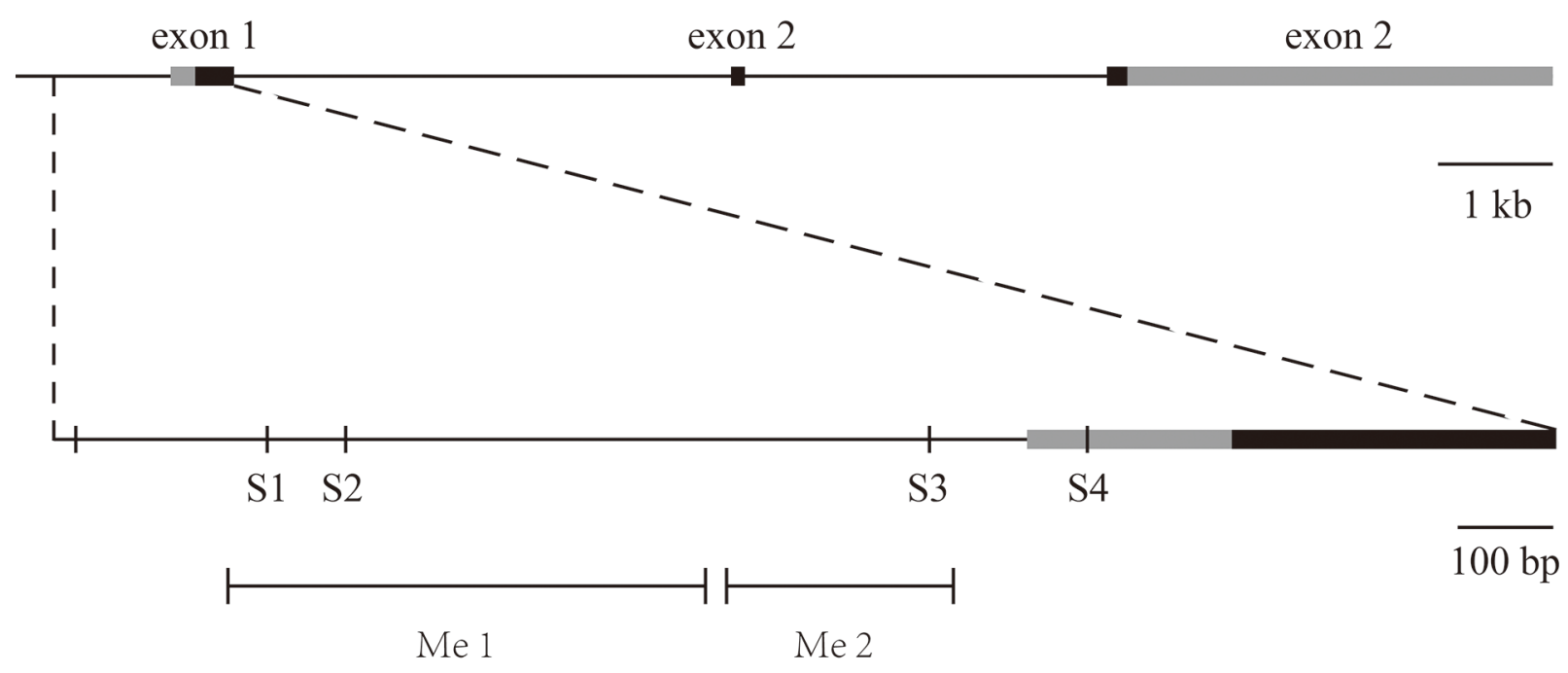

Me1 and Me2 Methylation analysis region by Bisulfite sequencing

Figure 2: The structure of the VHL gene and its detected $5 \mathrm{hmC}$ sites. 
A

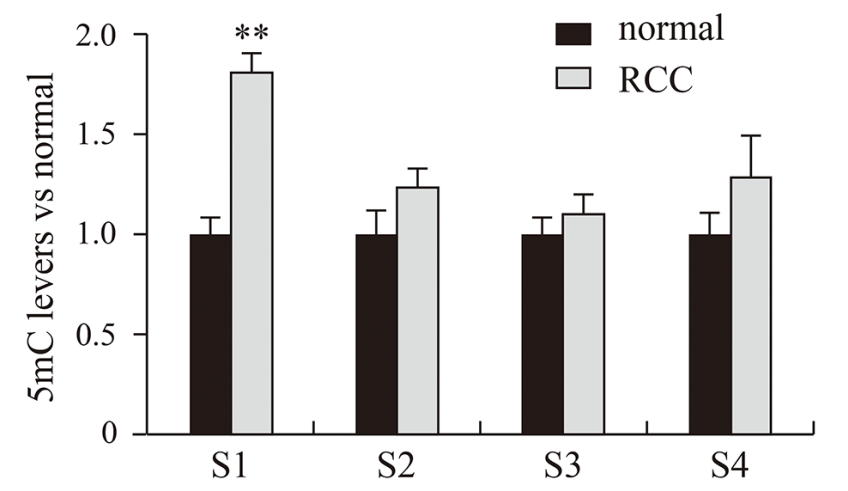

C

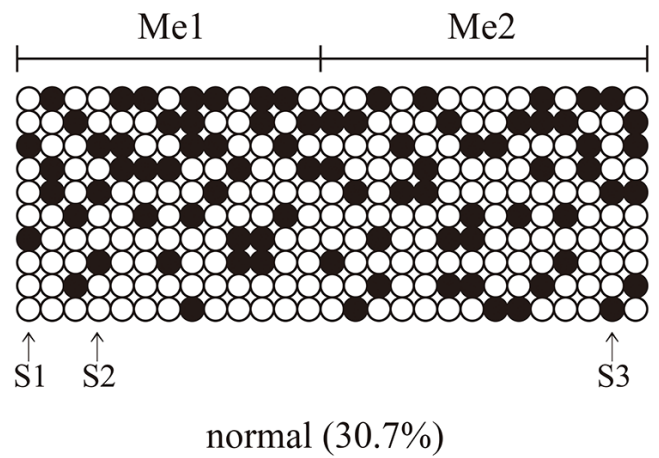

B
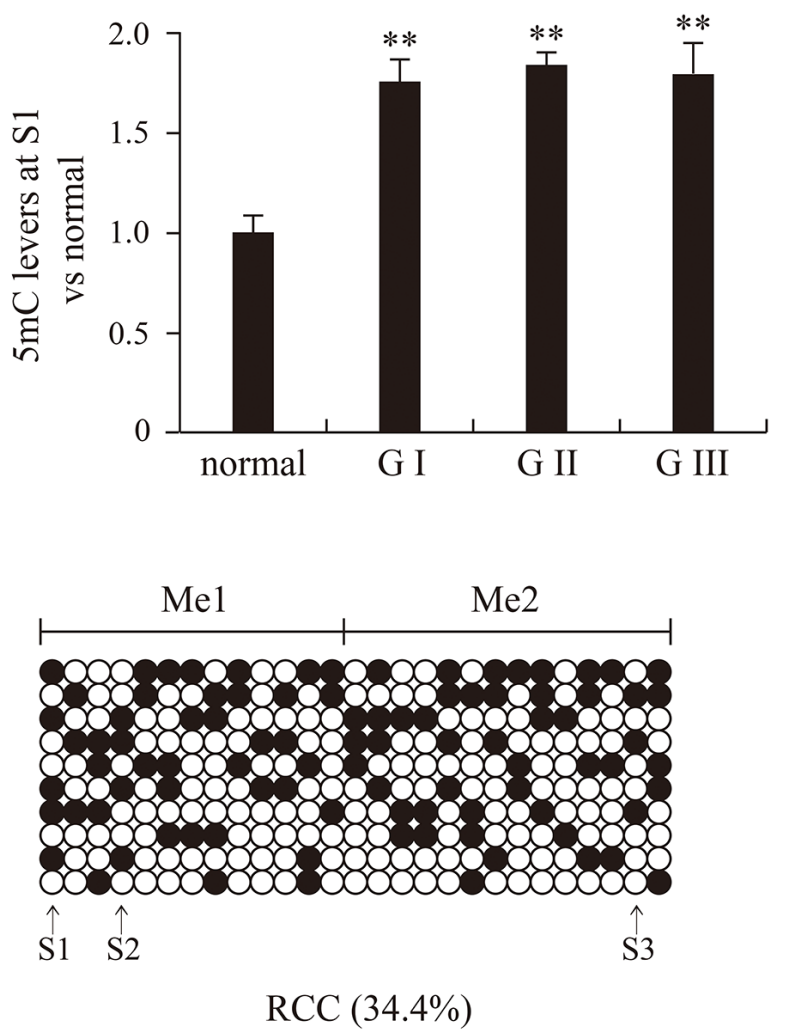

Figure 3: $5 \mathrm{mC}$ analysis of normal, RCC tissues and different RCC grades with bisulfite treatment combined with PCR products sequencing (A, B) and real time PCR (C) methods. RCC and normal indicate renal clear cell carcinoma and matched adjacent benign tissues. $\mathrm{G}$ indicates the pathological grade of RCC. ${ }^{*} \mathrm{P}<0.01$ vs. normal. Me1 and Me2 indicate the two $5 \mathrm{mC}$ regions detected. Filled and open circles represent methylated and unmethylated CG dinucleotides, respectively. S1, S2, S3 and S4 indicate four MSPI sites (CCGG).

A

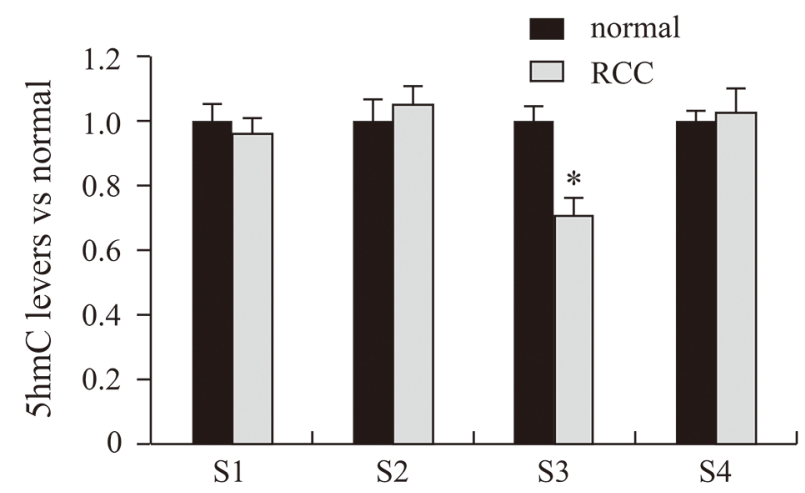

B

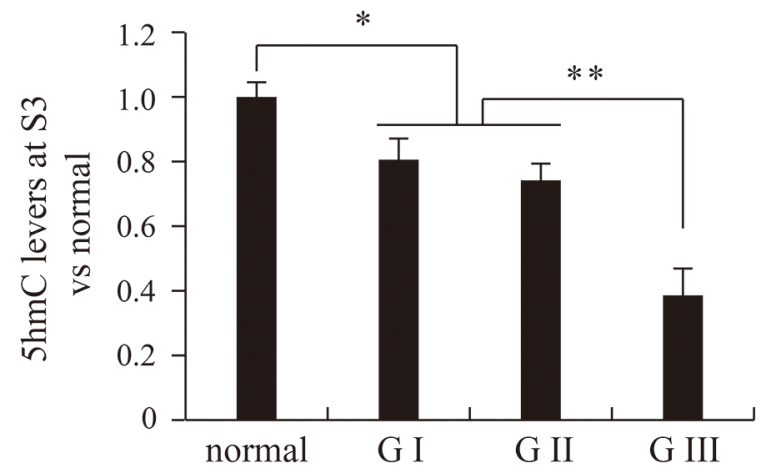

Figure 4: VHL 5hmC analysis of normal, RCC tissues and different RCC grades. RCC and normal indicate renal clear cell carcinoma and matched adjacent benign tissues. S1, S2, S3 and S4 indicate the four Msp I sites (CCGG) used for 5hmC analysis. G indicates the pathological grade of RCC. ${ }^{*} P<0.05, * * P<0.01$ vs. normal. 
Table 1: Clinical features of renal clear cell carcinoma

\begin{tabular}{|c|c|}
\hline Characteristics & Patients $(n=97)$ \\
\hline \multicolumn{2}{|l|}{ Gender } \\
\hline Female & $\mathrm{n}=45(46 \%)$ \\
\hline Male & $\mathrm{n}=52(54 \%)$ \\
\hline \multicolumn{2}{|l|}{ Age } \\
\hline$\leq 50$ & $\mathrm{n}=4(4 \%)$ \\
\hline $50 \sim 60$ & $\mathrm{n}=63(65 \%)$ \\
\hline $60 \sim 70$ & $\mathrm{n}=22(23 \%)$ \\
\hline$\geq 70$ & $\mathrm{n}=8(8 \%)$ \\
\hline \multicolumn{2}{|l|}{ Fuhrman grade } \\
\hline Low: 1 & $\mathrm{n}=28(29 \%)$ \\
\hline Low: 2 & $\mathrm{n}=34(35 \%)$ \\
\hline High: 3 & $\mathrm{n}=35(36 \%)$ \\
\hline High: 4 & $\mathrm{n}=0(0 \%)$ \\
\hline \multicolumn{2}{|l|}{ Tumor location } \\
\hline Left & $\mathrm{n}=51(53 \%)$ \\
\hline Right & $\mathrm{n}=46(47 \%)$ \\
\hline \multicolumn{2}{|l|}{ Tumor size } \\
\hline$>7 \mathrm{~cm}$ & $\mathrm{n}=56(58 \%)$ \\
\hline$\leq 7 \mathrm{~cm}$ & $\mathrm{n}=41(42 \%)$ \\
\hline Tumor metastasis & $\mathrm{n}=35(36 \%)$ \\
\hline Tumor necrosis & $\mathrm{n}=24(25 \%)$ \\
\hline Collecting system invasion & $\mathrm{n}=21(22 \%)$ \\
\hline Perirenal fat invasion & $\mathrm{n}=28(30 \%)$ \\
\hline Sinus fat invasion & $\mathrm{n}=4(4 \%)$ \\
\hline Renal vein invasion & $\mathrm{n}=45(46 \%)$ \\
\hline
\end{tabular}

not vary among Grades 1-II, though VHL expression was significantly decreased in grade III. This suggests other mechanisms are more strongly influence VHL expression.

TET1 and TET2 catalyze the transformation from $5 \mathrm{mC}$ to $5 \mathrm{hmC}$ and vice versa. Localization of $5 \mathrm{hmC}$ in regulatory regions such as transcription factor binding sites, promoters, and enhancers suggests that $5 \mathrm{hmC}$ has important regulatory functions $[18,19]$. We found that like VHL expression, $5 \mathrm{hmC}$ levels were significantly decreased in RCC tissues and were reduced further in pathological grade III tissue than grades I and II tissue. This suggests that $5 \mathrm{hmC}$, not $5 \mathrm{mC}$, participates in the regulation of VHL expression. To explore that idea further, we assessed the expression of TET1 and TET2, which could activate VHL expression by converting
$5 \mathrm{mC}$ to $5 \mathrm{hmC}$ in the gene's promoter region [20]. Our findings indicate that TET1 expression is significantly lower pathological grade III RCC tissue than in grades I and II, which corresponds to the levels of both $5 \mathrm{hmC}$ and VHL. This finding is consistent with earlier observations that TET1 is an essential tumor suppressor in prostate and breast cancers [21,22]

In sum, our findings indicate that levels of $5 \mathrm{hmC}$ on VHL are lower in RCC tissues than matched adjacent benign tissues, and that the levels of VHL $5 \mathrm{hmC}$ are lower in pathological grade III RCC than grades I and II. By contrast, level of $5 \mathrm{mC}$ on VHL did not differ among tissues. It thus appears that the level of $5 \mathrm{hmC}$ on VHL regulates the gene's expression and may be participate in the occurrence and development of RCC. 
Table 2: PCR products, primer sequences and PCR efficiency

\begin{tabular}{|c|c|c|c|c|c|c|}
\hline PCR product & Sample & Left primer & Right primer & $\begin{array}{l}\text { Size } \\
\text { (bp) }\end{array}$ & $\mathbf{R}^{2}$ & PCR efficiency \\
\hline VHL S1 & DNA & cttgtgatcagcccacttcagc & Gtcatgtttcctgecttcactg & 144 & 0.998 & 98.82 \\
\hline VHL S2 & DNA & atgacgcttttattgaagtgcag & tattaaggccctactatgtaccac & 102 & 0.997 & 97.16 \\
\hline VHL S3 & DNA & cgcctacagtaccaactactcg & tgagacagggtctcactctgtc & 129 & 0.999 & 99.28 \\
\hline VHL S4 & DNA & tacagtaacgagttggcctagc & gctcggtagaggatggaacg & 126 & 0.990 & 107.13 \\
\hline VHL Me1-O & DNA & aggttttattatgttgttaggttgg & aattacaaaccttaaccactatacc & 566 & - & - \\
\hline VHL Me1-I & DNA & aaagtattgggattataggtatgag & accttaaccactatacctaataaac & 499 & - & - \\
\hline VHL Me2-O & DNA & tttgtaatttttgtattttgagagg & tttttaaaacaaaatctcactctatc & 268 & - & - \\
\hline VHL Me2-I & DNA & taggaggattatttgaatttaggag & tttttaaaacaaaatctcactctatc & 237 & - & - \\
\hline Control & DNA & getctgcccatagatgectttg & tccctggttttgacctggggga & 91 & 0.999 & 102.52 \\
\hline VHL & mRNA & tctctcaatgttgacggacagc & gatcttcgtagagcgacctgac & 148 & 0.992 & 99.13 \\
\hline TET1 & mRNA & gcacataagataagggcagtgg & acttcaggttgcacggtctcag & 137 & 0.992 & 101.19 \\
\hline TET2 & mRNA & taggacatgatccaggaagagc & caggaatggacttagtctgttgc & 142 & 0.996 & 98.86 \\
\hline GAPDH & mRNA & aaggtgaaggtcggagtcaac & tgaaggggtcattgatggcaac & 106 & 0.998 & 99.37 \\
\hline
\end{tabular}

$\mathrm{R}^{2}$ is the correlation coefficient. VHL Me1/2-O and VHL Me1/2-I are the outer and inner primers in methylation analysis of the region "Me1/2" through nested PCR. VHL S1, S2, S3 and S4 indicate the four MspI sites (CCGG) used for 5hmC analysis.

\section{MATERIALS AND METHODS}

\section{Patients and samples}

A total of 97 frozen RCC tissue samples from patients with RCC and matched adjacent benign tissues were collected at the First Affiliated Hospital of Harbin Medical University and the Tumor Hospital of Heilongjiang Province between 2010 and 2015. Among the 97 RCC patients, the median age was 56. The clinical information for the patients is listed in Table 1. All patients provided informed consent for the experimental use of the surgical samples. The tissue specimens were snap frozen and stored at $-80^{\circ} \mathrm{C}$ until used for experiments.

\section{DNA extraction and RNA isolation}

Approximately $40 \mathrm{mg}$ each of RCC tissue and adjacent benign tissue were separately ground and divided into two equal parts for extraction of DNA and RNA. Genomic DNA was extracted using a DNA Extraction Kit (Tiangen, Beijing, China) according to the kit's specifications. Total RNA was isolated using TRIzol reagent (Invitrogen) according to the manufacturer's instructions. The RNA samples were treated with Amplification Grade DNase I (TaKaRa, Tokyo, Japan) for $60 \mathrm{~min}$ at room temperature. First strand cDNA was synthesized using a RevertAid ${ }^{\mathrm{TM}}$ First Strand cDNA Synthesis Kit (TaKaRa).

\section{Detection of 5-hmC}

DNA used for $5 \mathrm{hmC}$ analysis was first glycosylated using a Quest 5-hmC Detection Kit ${ }^{\mathrm{TM}}$ (Zymo Research, Irvine, CA) according to the manufacturer's instructions. Thereafter, glucose-5hmC-sensitive restriction endonucleases were able to cut the $\mathrm{C}$ and $5 \mathrm{mC}$ sites, but not the $5 \mathrm{hmC}$ sites. As a result, VHL $5 \mathrm{hmC}$ could be detected with real-time PCR using the treated DNA as a template. We used the $\Delta \Delta \mathrm{Ct}$ values (glucosylated-unglucosylated) to assess the $5 \mathrm{hmC}$ levels in the RCC and control tissues for all PCR fragments tested.

\section{Real-time PCR and western blot analysis}

To detect $5 \mathrm{hmC}$ expression using real-time PCR, primers were designed based on the $5 \mathrm{hmC}$ sites in the VHL genomic sequence or the sequence of VHL mRNA. All primers are listed in Table 2. Real-time PCR was performed using an ABI 7500 system with SYBR®Premix Ex Taq ${ }^{\mathrm{TM}}$ (Takara) according to the manufacturer's instructions. The housekeeping gene GAPDH was used as internal control to evaluate relative expression levels.

Normal and RCC tissues were ground, and the total protein was isolated in lysis buffer and PMSF. Aliquots of protein were separated on SDS-PAGE, transferred to a PVDF membrane and detected using the anti-VHL, anti-TET1 and anti- $\beta$-actin antibodies (Cell signaling technology, Boston, MA). 


\section{Analysis of 5mC}

All samples for $5 \mathrm{mC}$ analysis were genomic DNA derived from RCC tissues and matched adjacent benign tissues. Genomic DNA was treated with a BisulFlash DNA Modification Kit (Zymo Research, Irvine, CA) before DNA methylation analysis. The treatment causes unmethylated cytosine to be converted to thymine, but the methylated cytosine remained unchanged. Real-time PCR and sequencing of the PCR products were then used for $5 \mathrm{mC}$ analysis. The real-time PCR method was similar to that used for $5 \mathrm{hmC}$ analysis. The PCR product sequencing enabled detection of CG dinucleotides and verified the accuracy of the real-time PCR method. To amplify CG dinucleotides, primers were designing primers based on the sequences after treatment. Thereafter, the PCR products were subjected to T-A cloning, and 10 positive clones were chosen for sequencing. The $5 \mathrm{mC}$ analysis entailed assessing the difference in CG dinucleotides between the original sequence and the sequencing results.

\section{Statistical analysis}

All data are presented as the average of three independent experiments. The $2^{-\triangle \Delta \mathrm{Ct}}$ method was used to calculate the relative expression and the $5 \mathrm{mC}$ and $5 \mathrm{hmC}$ levels in each gene. Statistical analysis was done using unpaired Student's $t$ test. Values of $p<0.05$ and $<0.01$ were considered significant.

\section{ACKNOWLEDGMENTS}

The study was supported by Harbin Technology and Innovation Foundation for Youth (Grant number 2016RAQXJ188).

\section{CONFLICTS OF INTEREST} interest.

The authors declare that they have no conflicts of

\section{REFERENCES}

1. López JI. Renal tumors with clear cells. A review. Pathol Res Pract. 2013; 209:137-146.

2. Ma X, Fan Y, Gao Y, Zhang Y, Huang Q, Ai Q, Ni D, Chen W, Zhang P, Song E, Wang B, Shi T, Zheng T, Zhang X. Dicer is down-regulated in clear cell renal cell carcinoma and in vitro Dicer knockdown enhances malignant phenotype transformation. Urol Oncol. 2014; 32:e9-17.

3. Lai AY, Wade PA. Cancer biology and NuRD: a multifaceted chromatin remodelling complex. Nat Rev Cancer. 2011; $11: 588-596$
4. Cancer Genome Atlas Research Network. Integrated genomic analyses of ovarian carcinoma. Nature. 2011; 474:609-615.

5. Kriaucionis S, Heintz N. The nuclear DNA base 5-hydroxymethylcytosine is present in Purkinje neurons and the brain. Science. 2009; 324:929-930.

6. Madzo J, Vasanthakumar A, Godley LA. Perturbations of 5-hydroxymethylcytosine patterning in hematologic malignancies. Semin Hematol. 2013; 50:61-69.

7. Kraus TF, Globisch D, Wagner M, Eigenbrod S, Widmann D, Münzel M, Müller M, Pfaffeneder T, Hackner B, Feiden W, Schüller U, Carell T, Kretzschmar HA. Low values of 5-hydroxymethylcytosine $(5 \mathrm{hmC})$, the "sixth base," are associated with anaplasia in human brain tumors. Int $\mathrm{J}$ Cancer. 2012; 131:1577-1590.

8. Orr BA, Haffner MC, Nelson WG, Yegnasubramanian $\mathrm{S}$, Eberhart CG. Decreased 5-hydroxymethylcytosine is associated with neural progenitor phenotype in normal brain and shorter survival in malignant glioma. PLoS One. 2012; 7:e41036.

9. Thomson JP, Hunter JM, Lempiäinen H, Müller A, Terranova R, Moggs JG, Meehan RR. Dynamic changes in 5-hydroxymethylation signatures underpin early and late events in drug exposed liver. Nucleic Acids Res. 2013; 41:5639-5654.

10. Wielscher M, Liou W, Pulverer W, Singer CF, RappaportFuerhauser C, Kandioler D, Egger G, Weinhäusel A. Cytosine 5-hydroxymethylation of the LZTS1 gene is reduced in breast cancer. Transl Oncol. 2013; 6:715-721.

11. Cuperlovic-Culf M, Cormier K, Touaibia M, Reyjal J, Robichaud S, Belbraouet M, Turcotte S. H NMR metabolomics analysis of renal cell carcinoma cells: effect of VHL inactivation on metabolism. Int J Cancer. 2016; 138:2439-2449.

12. Shahzad H, Kehar SI, Ali S, Tariq N. Expression of Von Hippel - Lindau (VHL) gene mutation in diagnosed cases of renal cell carcinoma. Pak J Med Sci. 2014; 30:880-885.

13. Gordan JD, Simon MC. Hypoxia-inducible factors: central regulators of the tumor phenotype. Curr Opin Genet Dev. 2007; 17:71-77.

14. Lutz MS, Burk RD. Primary cilium formation requires von Hippel-Lindou gene function in renal derived cell. Cancer Res. 2006; 66:6903-6907.

15. Ficz G, Gribben JG. Loss of 5-hydroxymethylcytosine in cancer: cause or consequence? Genomics. 2014; 104:352-357.

16. Kuroda N, Karashima T, Inoue K, Kasajima A, Ohe C, Kawakami F, Mikami S, Matsuura K, Moriyama M, Nagashima Y, Petersson F, Lopez JI, Cohen RJ, et al. Review of renal cell carcinoma with rhabdoid features with focus on clinical and pathobiological aspects. Pol J Pathol. 2015; 66:3-8.

17. Stroud H, Feng S, Morey Kinney S, Pradhan S, Jacobsen SE. 5-Hydroxymethylcytosine is associated with enhancers 
and gene bodies in human embryonic stem cells. Genome Biol. 2011; 12:R54.

18. Madzo J, Liu H, Rodriguez A, Vasanthakumar A, Sundaravel S, Caces DB, Looney TJ, Zhang L, Lepore JB, Macrae T, Duszynski R, Shih AH, Song CX, et al. Hydroxymethylation at gene regulatory regions directs stem/early progenitor cell commitment during erythropoiesis. Cell Rep. 2014; 6:231-244.

19. Pastor WA, Pape UJ, Huang Y, Henderson HR, Lister R, Ko M, McLoughlin EM, Brudno Y, Mahapatra S, Kapranov P, Tahiliani M, Daley GQ, Liu XS, et al. Genome-wide mapping of 5-hydroxymethylcytosine in embryonic stem cells. Nature. 2011; 473:394-397.
20. Jones PA, Laird PW. Cancer epigenetics comes of age. Nat Genet. 1999; 21:163-167.

21. Hsu CH, Peng KL, Kang ML, Chen YR, Yang YC, Tsai $\mathrm{CH}$, Chu CS, Jeng YM, Chen YT, Lin FM, Huang HD, Lu YY, Teng YC, et al. TET1 suppresses cancer invasion by activating the tissue inhibitors of metalloproteinases. Cell Rep. 2012; 2:568-579.

22. Sun $M$, Song $C X$, Huang $H$, Frankenberger CA, Sankarasharma D, Gomes S, Chen P, Chen J, Chada KK, He C, Rosner MR. HMGA2/TET1/HOXA9 signaling pathway regulates breast cancer growth and metastasis. Proc Natl Acad Sci USA. 2013; 110:9920-9925. 